\title{
Persepsi Siswa Tentang Pelaksanaan Bimbingan dan Konseling di Sekolah Menengah Atas
}

\author{
Badrul Kamil, Pendi Ilham
}

\author{
Dosen dan Mahasiswa Fakultas Tarbiyah dan Keguruan, IAIN Raden Intan Lampung \\ Diterima: Oktober 2015. Disetujui: November 2015. Dipublikasikan: Desember 2015
}

\begin{abstract}
Abstrak: Persepsi siswa SMA Negeri Pesisir Tengah umumnya tidak memiliki pemahaman tentang Pedoman Konseling Integral. Ada tiga kelompok pendapat dalam memahami bimbingan konseling (BK), Pertama, siswa yang menganggap bahwa bimbingan bimbingan (BK) sebagai supervisor disipliner terhadap peraturan sekolah disamping masalah lainnya. Kedua, bimbingan konseling (BK) sebagai upaya untuk membantu siswa dalam menangani masalah, terutama masalah disiplin siswa terhadap disiplin sekolah, dan Ketiga, siswa yang memahami BK sebagai pembimbing membimbing dan membimbing siswa, untuk membantu siswa memahami diri mereka sendiri dan membantu memecahkan masalah yang dihadapi siswa menjadi lebih baik, termasuk disiplin. Secara umum, pemahaman siswa tentang Pedoman Konseling adalah sebagai badan penanganan keamanan pelajar. Adapun prinsip-prinsip yang ada dalam Bimbingan Konseling dalam proses kegiatan belum dipahami. Dengan demikian, dalam program siswa, target pelayanan konseling dalam proses aktivitas belum terpenuhi. Dengan demikian dalam pemahaman siswa, sasaran layanan konseling atau siswa yang berkaitan dengan Konseling dan Bimbingan adalah siswa yang memiliki masalah sekolah.
\end{abstract}

Kata Kunci: Bimbingan Konseling, Persepsi, Siswa

\section{Pendahuluan}

Pengembangan kemanusiaan kemanusiaan seutuhnya hendaknya mencapai pribadipribadi dengan kemandirian matang. Kemampuan sosial yang menyejukkan, kesusilaan yang tinggi, dan keimanan serta ketakwaan yang dalam (Anti, 1994). Kenyataan yang sering dijumpai pada saat ini adalah keadaan pribadi yang kurang berkembang dan rapuh, kesusilaan dan moral yang rendah, keimanan dan ketakwaan yang dangkal. Selain itu banyak siswa yang kurang dapat mengembangkan sesuai bakatnya, yang berkecedasan tinggi kurang dapat mengoptimalkannya. Tingkat kenkalan remaja dan perkelahian pelajar yang semakin meningkat ini menunjukan gejala kurang berkembangnya dimensi kesosialan dan kesusilaan mereka. Perubahan yang terjadi dan makin kompleksnya keadaan masyarakat akan makin meningkatkan derajat rasa tidak aman bagi para remaja dan pemuda. Akibat yang akan timbul adalah semakin banyaknya individu, anak-anak dan remaja disekolah, para pemuda serta warga masyarakat lainnya yang dihimpit oleh berbagai tantangan dan ketidakpastian, terlempar dan terhempas oleh berbagai harapan dan keinginan yang tidak terpenuhi. Kehendak akan pengemnbangan secara optimal individuakitas, sosialitas, moralitas dan religiositas dalam rangka pembentukan manusia seutuhnya semakin mendapat tantangan (Anti, 1994).

Disinilah dirasakan perlunya yang luas bimbingan konseling di samping legiatan pengajaran. Dalam tugas pelayanan yang luas bimbingan konseling disekolah adalah pelayanan untuk semua murid yang mengacu pada keseluruhan perkembangan mereka yang meliputi dimensi kemanusiaannya dlam rangka mewujudkan manusia seutuhnya. Menurut Hallen, bahwa pada umumnya di dalam kegiatan pendidkan formal, sekurang-kurangnya ada tiga ruang lingkup kegiatan pendidikan, yaitu: bidang pembinaan pribadi (A, 2002). Kegiatan Bimbingan Konseling merupakan bidang pembinaan pribadi yang memfokuskan kegiatannya dalam membantu para siswa secara pribadi agar mereka dapat berhasil dalam kegiatan belajar. Lebih lanjut Hallen menuturkan bahwa perbuatan belajar dapat menimbulkan berbagai masalah baik, yang berhubungan dengan siswa yang belajar maupun dengar pengajar/guru itu sendiri (A, 2002). Sedangkan di pihak pengajar masalah yang muncul adalah seperti bagaimana 
menciptakan suasana dan kondisi yang baik, sehingga perbuatan belajar dapat berhasil dengan baik, masalah memilih metode dan media yang tepat sesuai dengan jenis ean situasi belajar, membuat rencaa belajar bagi para siswa. Menyesuaikan proses belajar dengan keunikan yang dimiliki para siswa, penilaian hasil belajar, diagnosa kesulitan belajar dan sebagainya. Lester D. Crow dan Alice Crow mengemukakan bahwa bimbingan merupakan bantuan yang dapat diberikan oleh pribadi yang terdidik dan wanita atau pria yang terlatih, kepada setiap individu yang usianya tidak ditentukan untuk dapat menjalani kegiatan hidup, mengembnagkan sudut pandangnya, mengambil keputusannya sendiri dan menanggung bebannya sendiri. (Sukardi, 1983).

Roger mengatakan bahwa konseling adalah serangkaian hubungan langsung dengan individu yang bertujuan untuk membantu dia dalam merubah sikap dan tingkah lakunya (A, 2002). melalui program pelayanan Bimbingan Konseling yang baik, maka setiap siswa diharapkan mendaptkan kesempatan untuk mengembangkan sikap potensi yang dimilikinya seoptimal mungkin, sehingga mereka dapat menemukan kebahgiaan pribadi dan kemanfaatan sosial (A, 2002). Pada umumnya pelaksanaan kegiatan bimbingan dan konseling disekolah kurang dapat berperan sebagaimana mestinya oleh para siswa. Kebanyakan para siswa hanya berhubungan dengan bimbingan konseling ketika mereka di panggil oleh guru bimbingan konseling karena mendapat teguran terhadap konsekuensi apa yang dilakukan siswa tersebut. Didalam Bimbingan Konseling terdapat 12 azas yaitu asaz kerahasiaan, azas kesukarelaan, azas keterbukaan, azas kekinian, azas kemandirian, azas kedinamisan, azas keterpaduan, azas kenormatifan, azas keahlian, azas alih tangan dan azas tut wuri handayani (Anti, 1994). Pada saat penulis mengadakan prasurvei di SMA Negeri I Pesisir Tengah Kabupaten Pesisir Barat, penulis memperoleh data dari hasil wawancara dengan Bapak Bandi selaku guru Bimbingan dan Konseling yang menjelaskan bahwa sebagian besar siswa di SMA Negeri I Pesisir ini tidak memahami tidak memahami bimbingan dan konseling disekolah belum pernah terlaksana (Ilham, 2014).

Menurut Jalaludin Rakhmat persepi adalah pengalaman tentang objek, peristiwa atau hubungan-hubungan yang diperoleh dengan menyimpulkan informasi dan menafsirkan pesan (Ina, 2014). Dalam persepektif ilmu komunikasi, persepsi bisa dikatakan sebnagai inti komunikasi, sedangkan penafsiran (interprestasi) adalah inti persepsi, yang identik dengan penyandian-balik (decoding) dalam proses komunikasi. Hal ini tampak jelas pada definisi Rudolph F. Varbender yang menyatakan bahwa persepsi adalah proses menafsirkan informasi duniawai (Ina, 2014). Persepsi memiliki peran yang sangat penting dalam keberhasilan komunikasi. Artinya, kecermatan dalam mempersepsi stimuli inderawai mengantarkan kepada keberhasilan komunikasi. Sebaliknya, kegagalan dalam mempersepsi stimuli, menyebabkan mis-komunikasi.

Dalam pembentukan persepsi melalui beberapa tahapan. Tahap-taap dalam proses persepsi tidaklah saling terpiasah. Dalam kenyataan, prosesnya bersifat kontinu, bercampurbaur, dan bertumpang tindih satu sama lain. Beberapa prinsip dasar mengenai persepsi yang harus guru ketahui agar ia dapat menjadi komunikator yang efektif, yaitu: (Slameto, Belajar dan Faktor-faktor yang mempengaruhinya , 2010) (a) Persepsi itu relatif bukan absolut (b) Persepi itu selektif (c) Persepsi itu mempunyai tatanan (d) Persepsi dipengaruhi oleh harapan dan kesiapan.Objek persepsi yang berwujud manusia ini disebut person perception atau juga ada yang menyebutkan sebagai social perception. Pada objek persepsi manusia, manusia yang dipersepsi mempunyai kemampuan-kemampuan, perasaan, ataupun aspek-aspek lain sepertihalnya pada orang yang mempersepsi. Orang yang dipersepsi akan dapat mempengaruhi pada orang yang mempersepsi, lingkungan yang melatarbelakangi objek persepsi, dan perseptor sendiri (Ina, 2014).

Menurut Winkel kata guidance berkaitan dengan guiding showing away (menunjukan jalan), leading (memimpin), conducting (penuntun), giving intruction (memberikan petunjuk), 
regulating (mengatur), govering (mengarahkan), giving advice (memberikan hadiah) (Anti, Dasar- dasar Bimbingan dan Konseling, 1994). Bimbingan dapat diartikan sebagai proses pemberian bantuan yang terus menerus dari seorang pembimbing yang telah dipersiapkan kepada individu yang membutuhkannya dalam rangka mengembangkan seluruh potensi yang dimilikinya secara optimal dengan menggunakan berbagai macam media dan teknik bimbingan dalam suasana asuhan yang normative agar tercipta kemandirian individu sehingga dapat bermanfaat bagi diri sendiri dan lingkungannya, sedangkan Konseling Moh. Surya mengungkapkan bahwa konseling itu dimanfaatkan olehnya dalam memperbaiki tingkah lakunya pada masa yang akan datang (Kusmawati, 2008). Konseling juga dapat diartikan sebagaimproses hubungan seorang dengan seorang, dimana yang seorang dibantu oleh orang lainnya untuk meningkatkan pengertian dan kemampuannya dalam menghadapi masalahnya (Anti, Dasar-dasar Bimbingan dan Konseling, 1994).

Dapat disimpulkan bahwa bimbingan dan konseling berusaha untuk memepertemukan antara kemampuan individu dengan cita-citanya serta dengan situasi dan kebutuhan masyrakat. Bimbingan dan Konseling memiliki fungsi yang cukup signifikan dalam upayanya membangun kembali kepribadian peserta didik, hal ini sesuai dengan apa yang disebutkan oleh Muh. Surya, bahwa: "ditinjau dari segi sifatnya. Layanan bimbingan dan konseling dapat berfungsi sebagai pencegahan (prefentif), pemahaman, perbaikan, serta pemeliharaan dan pengembangan (Surya, 1998). Dengan demikian fungsi Bimbingan dan Konseling ini dapat didayagunakan sebagai salah satu media dan metode untuk mengembangkan kepribadian pesertadidik. Untuk lebih jelas diuraikan fungsi-fungsi yang terdapat di Bimbingan dan Konseling, (a) Fungsi pecegahan. Layanan bimbingan dapat berfungsi pencegahan artinya merupakan usaha pencegahan terhadap timbulnya masalah (b) Fungsi Pemahaman. Fungsi bimbingan dan konseling yang akan menghasilkan pemahaman tentang sesuatu oleh pihak-pihak (c) Fungsi Perbaikan. Fungsi bimbingan dan konseling yang akan menghasilkan terpecahkannya atau teratasinya berbagai permasalahan yang dialami peserta didik (d) fungsi Pemeliharaan dan Pengembangan. Fungsi ini untuk mengarahkan peserta didik dalam memelihara dan mengmebnagkan keseluruhan pribadinya secara mantap, terarah dan berkelanjutan. Setiap layanan dan kegiatan bimbingan dan konseling haruslah dilaksankan secara langsug mengacu pada salah satu fungsi itu, agar hasil ynag hendak dicapainya secara jelas dapat diidentifikasikan dan dievaluasi.

Bimbingan dan Konseling memiliki tujuan-tujuan sebagai berikut: (a) Tujuan Umum. Tujuan umum layanan Bimbingan dan Konseling adalah sesuai dengan tujuan pendidikan, sebagaimana dinyatakan dalam Undang-Undang Sistem Pendidikan Nasional (UUSPN) Tahun 1989 (UU No.2/1989). (b) Tujuan Khusus. Secara khusus layanan Bimbingan dan Konseling bertujuan untuk membantu peserta didik agar dapat mencapai tujuan-tujuan perkembangan meliputi aspek pribadi sosial, belajar, dan karier. Dalam menyelenggarakan layanan Bimbingan dan Konseling di sekolahhendaknya selalu mengacu pada asas-asas bimbingan dan konseling. Asas-asas ini dapat diterapkan sebagai berikut: (1) Asas Kerahasiaan, (2) Asas Kesukarelaan, (3) Asas Keterbukaan, (4) Asas Kekinin, (5) Asas Kemandirian, (6) Asas Kegiatan, (7) Asas Kedinamisan, (8) Asas Keterpaduan, (9) Asas Kenormatifan, (10) Asas Keahlian, (11) Asas Alih Tangan Kasus (12) Asas Tut Wuri Handayani. Asas kerahasian merupakan asas kunci dalam upaya bimbingan dan konseling. Jika asas ini benar- benar dijalankan maka penyelenggara bimbingan dan konseling akan mendapat kepercayaan dan para peserta didik dan layanan bimbingan konseling akan dimanfaatkan secara baik oleh peserta didik, jika sebaliknya para penyelenggara bimbingan konseling tidak memperhatikan asas tersebut, Layanan Bimbingan dan Konseling tidak mempunyai arti lagi nagi para peserta didik.

\section{Metode Penelitian}


Pada penelitian ini peneliti telah melakukan pengamatan yang dilakukan di SMA Negeri I Pesisir Tengah Pesisir Barat. Untuk keperluan mendapatkan data penelitian dibutuhkan responden yang mengetahui seleuk beluk SMA Negeri I Pesisir Tengah Pesisir Barat yaitu peserta didik dan Guru Bimbingan dan Konseling dengan menggunakan SnowBalling Sample. Penelitian ini menggunakan pendekatan kualitatif. Menurut Bogdan dan Tayloor yang dikutip oleh Lexy J. Moloeng mengatakan bahwa metodologi kualitatif sebagai produser penelitian yang menghasilkan data deskriptif berupa kata tertulis/lisan dari orangorang dan perilaku yang diamati (Moloeng, 1999). Sedangkan desain penelitian ini bersifat deskriptif. Dalam penelitian ini akan di gambarkan tentang persepsi peserta didik tentang bimbingan dan konseling dan keaktifan peserta didik dalam pelaksanaan bimbingan dan konseling di SMA Negeri I Pesisir Tengah Kabupaten Pesisir Barat sehingga diakhir penelitian akan diperoleh gambaran umum yang komprehensif tentang hal tersebut.

\section{Hasil dan Pembahasan}

Dalam penyajian data ini penulis menggunakan metode penelitian kualitatif yaitu penelitian yang menghasilkan data deskriptif berupa kata-kata atau lisan dari orang-orang dan perilaku yang diamati. Kelancaran pelaksanaan layanan Bimbingan Konseling disekolah dipengaruhi oleh beberapa faktor, yaitu guru BK, Kepala Sekolah dan guru-guru mata pelajaran, sarana dan prasarana, program kerja dan nuga peran serta siswa disekolah. Untuk dapat mencapai hasil yang maksimal dalam pelayanan Bimbingan dan Konseling tentunya semua pihak disekolah ikut berperan serta dalam menunjang pelaksanaan. Salah satunya adalah siswa. Bagaimana siswa dapat memanfaatkan dengan baik sebagaimana mestinya. Siswa sebagai subyek sekaligus obyek dalam Bimbingan Konseling. Maksudnya adalah Bimbingan Konseling dilaksanakan untuk agar siswa agar dapat membantu siswa dalam proses belajar di sekolah menjadi pribadi yang matang dalam Bimbingan Konseling. Maksudnya adalah bahwa Bimbingan Konseling dilaksankan untuk siswa agar dapat membantub siswa dalam proses belajar diseolah menjadi pribadi yang matang dalam usaha mencapai tujuan pendidikan. Oleh karenanya dalam proses BK siswa seharusnya terlibat/berperan aktif, sehingga BK dapat berjalan dengan baik. Siswa akan berperan serta dalam proses BK, ketika siswa mampu memhami dengan baik apa itu Bk disekolah. Dapat dikatakan persepsi siswa tentang BK akan mempengaruhi pada pelaksaan dan pemanfaatanya. SMAN 1

Pesisir Tengah sebagai profil pendidkan dalam mencapai tujuan pendidikan nasional memliki tujuan Pendidikan Nasional. Adapun tujuannya adalah menghasilkan output yang memiliki aklak mahmudah, berilmu, beriman dan ikhlas. Untuk menghasilkan output yang berakjlak baik dan berkepribadian tentunya perlu pembinaan yang berkesinambungan. Bimbingan konseling disekolah merupakan bidang pembinaan siswa bekerja sama dengan guru- guru bidang studinya laiinya, karennaya bimbingan konseling diskeolah perlu dimanfaatkan dengan baik oleh siswa dan guru disekolah. Berdasarkan pengamatan penulis, siswa belum optimal memnfaatkan bimbingan konseling disekolah, hal ini disebabkan persepsi siswatentang BK disekolah tersebut dan bimbingan konseling pada umumnya belum terpahami dengan biak.

Sebagaimana yang dipahami siswa SMAN 1 Pesisir Tengah BK disekolah, ada beberapa yang hampir sama dan ada yang berbeda dengan lainnya. Dari kegiatan siswa tentang persepsi BK yang diuraikan diatas, satu orang siswa yang mempersepsi BK dengan cukup baik, yaitu beranggapan BK sebagai pembimbing siswa, membantu siswa memahaminya dan memecahkan masalah yang dihadapi agar siswa lebih memahami diri dan bersikap lebih baik, termasuk didalamnya kedisiplinan, dengan demikian menurutnya peran dan fungsi BK disekoalh adalah membimbing siswa agar tidak bersikap buruk dan membantu memecahkan masalah siswa. Siswa dapat berhubungan dengan BK untuk masalah pribadi, belajar dan 
pergaulan, sedangkan peranan BK diskeolah meurtnya tempat pencurahan apa yang terasa dihati dan bersangkutan oleh siswa yang berhubungan dengan masalah belajar, sosila pribadi sedangkan fungsinya membantu memecahkan masalah siswa dan mengarahkan untuk disiplin. Hal yang penting pelaksanaan BK adalah adanya azas dan prinsip sehingga BK dilaksanakan dengan biak. Seperti yang disebutkan oleh prayitno. Ada 12 azas yaitu kerahasiaan, keterpaduan, kenormatifan, keahlian, alih tangan dan tut wuri handayani (Amti, 2009). Dengan demikian persepsi siswa tentang BK sangat dipengaruhi oleh informasi tentang BK yang benar, pemahamn, pengamatan, dan pengamalan yang dimiliki terhadap BK disekolah.

\section{Simpulan dan Saran}

Berdasarkan penelitian yang dilakukan, peresepsi siswa rendah dikarenakan ada 3 kelompok pendapat: 1. Pendapat yang mempersepsikan bahwa BK adalah badan yang menangani permasalahan kedisipinansiswa terhadap aturan sekolah, disamping mengatasi masala lainnya. 2. Pendapat yang mempersepsikan Bk sebagai pembimbing siswa, membantu siswa memahami dirinya dan membntu mmecahkan masalah yang dihadapi siswa. 3. Pendaat yang mempersepsikan bahwa BK adalah badan pengawas sekolah. Secara umum dapat dikatakan bahwa Bk yang dipahami oleh siswa-siswa tersebut berkaitan dengan kedisiplinan siswa disekolah, siswa belum memahami sepenuhnya nahwa BK disekolah bertujuan agar dirinya dapat optimal dalam berkembang termasuk bakat dan minantnya.

\section{Daftar Pustaka}

A, H. (2002). Bimbingan dan Konseling dalam Islam. Jakarta : Ciputat Press.

Amti, P. \&. (2009). Dasar-Dasar Bimbingan dan Konseling. Jakarta: Rineka Cipta.

Anti, P. d. (1994). Dasar-dasar Bimbingan dan Konseling. Jakarta : Rineka Cipta.

Ilham, P. (2014). persepsi siswa tentang pelaksaan bimbingan dan konseling di sekolah menengah atas. (b. Bandi, Interviewer)

Ina, M. (2014, maret 20). http://eprints.uny.ac.id/9686/3/bab\%202.pdf. Retrieved from BAB II Kajian Teori. Konsep Dasar Tentang Persepsi.

Kusmawati, D. K. (2008). Proses Bimbingan dan Konselingdi Sekolah . Jakarta: Rineka Cipta.

Moloeng, L. J. (1999). Metodologi Penelitian Kulitatif. Bandung: Remaja Rosda Karya.

Slameto. (2010). Belajar dan Faktor-faktor yang mempengaruhinya . Jakarta : Rineka Cipta.

Sukardi, D. K. (1983). Dasar-Dasar Bimbingan dan Penyuluhan di sekolah . Denpasar: Usaha Nasional.

Surya, M. (1998). Dasar-Dasar Konseling Pendidikan, (Teori dan Konsep). Yogyakarta: kota kembang. 
